\title{
Undergraduate Students' Perception on Videotaping
}

\author{
D A Batunan 1 \\ ${ }^{1}$ Universitas Negeri Manado, Indonesia \\ corresponding author: deisyi2014@yahoo.co.id
}

\begin{abstract}
The industrial industry has influenced humans' lives and changed many aspects including the way how people learn. It is a challenge for the teachers to integrate technologhy into their classrooms. Reading activities on the FL classrooms should not tend to be reading texts and answering a series of questions anymore. The purpose of this study is to explore students' perception on the implementation of videotaping. Twenty five students' perception on it were explored through the use of interviews. The result showed that the students had a positive atitude toward it despite the fact of some issues might arise like tecnical, content and delivery.
\end{abstract}

Keywords: Videotaping, perception, creativity, self-reflection

\section{Introduction}

Education 4.0 has been the centre of the latest discussion and is much influenced by the history of industrial revolution. As the name suggests, revolution industrial refers to a dramatic and distruptive change on agricultural, manufacture, mining, transportation and many more that significantly alter many aspects of humans' lives including the way they work, live and communicate due to the advancement of science. Industrial revolution has experienced four stages as pointed out by Shwab (2016) in Hussin (2018) starting from the first industrial revolution to the latest one, the fourth industrial revolution. Each phase has its own characteristics and each phase is developed to contribute much more to humans' civilization. Hussin (2018) states " Education 4.0 is a response to the needs of IR (industrial revolution) 4.0 where human and technologhy are aligned to enable new possibilities" (p.92). In other words, teaching and learning on the classrooms is in challenge to seek innovations to accomodate and keep up with the latest era's demand by maximizing the role of technologhy and teachers which teacher should integrate technologhy into classrooms to better the education's quality.

The advancement on technologhy should be wholeheartly embraced by teachers due to many factors such the offered possibilities by technologhy to improve teaching at classrooms, the challenging situation to be faced on this fourth revolution industry, and the characteristics of the students that teachers will face on this millineal area. Teachers can not be replaced by technologhy, yet, technologhy aids teachers' job to be more efficient and effective. Teachers are not anymore seen the only source of learning and students have the privilege to have unlimited access to learning sources and learning can be done anytime anywhere because of technologhy advancement. These possiblities need to be considered and embraced. Massive number of studies show that the use of technologhy at the classroom facilitate and 
promote learning process (Plester, Wood, \& Joshi, 2009 in Yudhiantara \& Nasir, 2017; Bull and Thompson, 2004 in Yudhiantara \& Nasir, 2017; Smythe \& Neufeld, 2010 in Yudhiantara \& Nasir, 2017; Sha, Looi, Chen, \& Zhang, 2012 in Yudhiantara \& Nasir, 2017; Lee, Lee \& Kweon, 2013 in Yudhiantara \& Nasir, 2017).

This era, the fourth revolution industrial, leaves a vacuum that needed to be filled out. The World Economic Forum (2016) emphasizes the ten required skills that should be nurtured to answer the fourth revolution industrial era as follows; complex problem solving, critical thinking, creativity, people management, coordinating with others, emotional intelligence, judgement and decision making, service orientation, negotiation and cognitive flexibility. It is clearly seen that this era seeks more than smart people who can handle the job but it needs creative and cticitical problem solvers and decision makers that can negotiate, collaborate and be able to manage other people with high emotional intellegence who put service as priority and have growth mindset. These challenges should be paid attention so that this situation will intrique and guide teachers to formulate and design learning process that can nurture these best qualities and these best qualities will shine out from the students.

Students as the centre of teaching and learning process must be given much attention. Teachers should accomodate students' needs and interests. As teachers currently teaching at this era, teachers should be aware about millineal and generation $\mathrm{Z}$ ' $\mathrm{s}$ characterisctics as known as digital natives that they are adept in using technologhy since they are born and raised with massive number of information and technologhy. A study conducted by Barnes and Noble College, it was found out that the students refuse to be passive learners. They are not interested in simplying showing up for classes, sitting through lectures and taking notes that they will memorize for an exam later on. Moreover, it highlights that they best learn by doing and they expect that digital learning tools should be deeply integrated into their education (Kozinsky, 2017:1). In the same vein, Prensky (2006) observes that in order to keep up with this era, teachers, should be able to seek out ways to involve students fully in teachers' decisions and activities and to be able to speak the digital language fluently rather than deliver conventional way of teaching like dull lectures and to apply a self-paced learning for diverse students' characteristics.

One form of well-known technologhy and much used in education around the globe is videos. Teachers can play the videos or ask the students to do videotaping. Yudhiantara and Nasir (2017) highight that the use of video recorder at mobile phone is a platform to see how far they understand the given subject matter by completing the given projects. A study conducted by Andy and Suharto (2017) concluded that the use of RRRV (reading, retelling, rehearsal and videotaping) is more effective than the use of RRR (reading, retelling and rehearsal) because videotaping gave opportunities for the students to have feedbacks from their presentation that they can improve their pronunciation, vocabulary, and speaking.

This present study would like to shed the light about the undergraduate students perception of video taping as their responses toward the texts that they read. It is worthdoing since there have not been any studies conducted on this topic and it is hoped that the results of this study could be references for future resaechers and contribute to the existing body literature and can be applied by other English teachers/ lecturers in their classrooms. 
Some people might see reading is a passive process. On the other hand, it is not, as it is well illustrated by Nuttall (1996: 5) saying that "The text is full of meaning like a jug full of water; the reader's mind soaks it up like a sponge. In this view, the reader's role is passive; all the work has been done by the writer and the reader has only to open his mind and let the meaning pour in". In fact, she futhermore explains that the process rarely goes straightforward like this. The reader can not always exactly fully digest the writer's intention on his writings due to a number of reasons like having limited vocabulary stock, reading unfamiliar topics, and sharing different language code with the target language. In order to understand the meaning, the reader should take his owrnership and responsibility toward the text by being actively engaged to construct the meaning of the text that he is reading.

In previous Basic Reading course, the researcher would usually taught the students some reading skills and instructed them to answer the given tasks on reading texts. This style is not relevant anymore with the milineal students' characteristics since they would like to take ownership on their learning and they are skillful using technologhy. Therefore, the researcher adjusted some ways to accomodate the students' needs. Reading is not merely the process of reading texts and answering the question, but, it is a complex process where the reader should be able to grasp the writer's purpose and "owning it" by being able to retell and modify the text with his own words by adding their perspectives and experiences. Therefore, the purpose of this research is to see how the first year students give response to the implementation of videotaping starting from choosing their own text to be presented, reading and understanding the chosen text, doing videotaping and its editing and uploading it on social media, Facebook in order to attain feedback and input from classmates and the lecturer.

\section{Research Method}

This study was carried out in one of the state universities in Manado on November to December 2018 to see students' perception of vidotaping at Basic Reading course. There were twenty five (25 freshman students of English Department in Manado (North Sulawesi) taking Basic Reading course in the odd semester 2018/2019 academic year took part in this research. The class consists of 6 males and 24 females aged from 18 to 20 and has different ethnics, religion, personalities and abilities. The program that they took in high school differed them one to another; some took science and natural program, others took social studies and the rest took language. The Basic Reading course aims to help the students to be passionate and good readers by experiencing both extensive and intensive reading activities in the classroom. The class experienced blended learning in which the students would meet face to face in the classroom and they would meet online using Facebook platform. The researcher conducted an interview to dig out students' perception about the implementation of videotaping on reading. The research was categorized as a qualitative research which focussed on some aspects including the benefits of videotaping, what students liked best from doing it, what problems students experienced and how they solved the problems, and what benefits they had. The texts were chosen based on students' interests. Then, they read on their selfpace, elaborated and put their perspectives on the text that they chose, recorded it on the video and published it on the Facebook. The data obtained from the participants 
was firstly transcribed, orgainzed based on the objectives of the research, and coded in order to give meaning to the findings.

\section{Findings and Discussion}

The results of this research shows that the students have a positive perception toward the application of videotaping at reading course.

\section{What students like best about videotaping}

From 30 students, most of the students liked doing the video taping and only one student did not enjoy doing the videotaping because it was the first time for her to do it. There are various reasons posed by the students to see the good side of doing video taping. Firstly, they mostly were encouraged to be creative; to be able think about novel concept and how to put it into videos and present it to the audience and edit it to make it more interesting by adding subtitle and other effects on it. Also, videotaping is a platform to express themselves and serves as stress-reliever.

Kinanti: Yang paling saya sukai adalah videotaping bisa mengasah kreativitas saya dimana saya dapat menambahkan animasi, gambar atau tulisan dan musik latar sehingga video terlihat menarik. Dengan menambahkan hal-hal tersebut diatas maka saya dapat mengekspresikan diri saya dengan menambahkan apa yang saya gemari seperti K-Pop dan soft instrument. Mengedit video ataupun gambar itu mengasyikkan dan cukup menghilangkan penat. Dengan memilah video yang akan di edit beserta musik dan animasi atau gambar yang akan digunakan, terkadang saya lupa waktu karena terlalu menikmati. (What I like most from videotaping is that it can hone my creativity in which I can put animation, pictures or writings, and background sound on the video to make it more interesting. By adding these things, I can express myself by adding things that I like best such as K-Pop and soft instrumental music. Sorting out the video, animation, and pictures that I am going to edit is fun and relaxing because I am into it).

It is very interesting to observe that the students mostly expresses that videotaping is much to do with creativity. Creativity is inseparable from humans' civilization and differs it from other creatures. In line with this finding, Maley and Peachey (2015) present the main reasons why someone should be creative. One of them is that creativity serves as a platform for self-expression in which someone be himself; complete and feel energized.

Secondly, students viewed that videotaping is a way to see their weaknesses and how to improve it as reflected by one of the subjects, Lucius. Lucius: Share video membantu melihat kelemahan dan kekurangan. Dengan merekam pembicaraan atau presentasi yang divideokan memang bisa terlihat segi yang harus diperbaiki; intonasi, suara, pengucapan, grammar, kepercayaan diri, mimik dan bahasa tubuh. (Sharing video helps me to see my weaknesses and things that I need to improve. By doing videotaping, it can be clearly seen that there are many aspects that need to be improved like intonation, voice, pronunciation, grammar, self-confidence, mimic and gestures).

From the subject's statement, it can be seen that videotaping serves as a paltform for him to do reflection. It encourages him to have self-awareness about the things that he still lacks. He is in the phase of experiental learning as suggested by Woolfe, 1992 in Kohohen (1993). Kohohen (1993) defines "experiental learning as 
an educational orientation which aims at integrating theoretical and practical elements of learning for a whole person approach, emphasising the significance of experience for learning"(p.2). The gap between the knowledge of what and the knowledge of how was bridged through the experiences that he experiences. He needed to complete the vidoetaping. In order to do it, he needs to experience process of choosing and reading and the text. Then, he needed to make a concept and deliver the video to the audience. By doing videotaping, he also can see how his knowledge of what and the knowledge of how is put into practice. Woolfe (1992) in Kohohen (1993: 2) highlights there are four components of experiental learning : (1) The student is aware of the processes which are taking place, and which are enabling the learning to occur. (2) The student is involved in a reflective which enables him/her to relate current learning to part, present and future even if these relationships are felt rather than thought. (3)The experience and content are personally significant: what is being learned and how it is being learned have a special importance for the person. (4) There is an involvement of the whole selfbody, thoughts and feelings and actions not just of the mind; in other words, the student is engaged as a whole person.

Thirdly, A subject, Dennis enjoyed doing videotaping since he saw it as a challenge for him. Dennis: Saya sebetulnya sangat menyukai aktivitas ini dibandingkan dengan hanya teori karena menurut saya presentasi ini menantang dan dapat mendorong mahasiswa untuk dapat lebih memahami apa yang dipelajari. (I honestly enjoyed doing this activity compared to only having theory because this presentation is challenging and encouraged students to understand better what they are learning). This statement supports the findings revealed on a study conducted by Barnes and Noble College (Kozinsky, 2017) that the students would like to get engaged on their learning rather than to be spooned-feeding. Students engagement on learning is crucial since it will make them get empowered and be responsible for their own learning.

\section{Problems encoutered and how students' solved the problems}

The problems related to videotaping are varied mostly about technical, content and delivery issues and the way subjects solved them were also different.

Emma: Masalah yang saya alami ketika pembuatan video yaitu terkadang saya melakukan beberapa kesalahan pengucapan sehingga saya harus mengulangi beberapa kali. (The problem that I face on making video is that I did some mispronunciation and I needed to repeat more than once. The second problem was related to bad internet connection). Futhermore, the subject was aware the importance of pronunciation which is very crucial and much to do with meaning. Emma: Jika terjadi kesalahan pengucapan maka adakalanya dapat mengubah arti atau makna dari kata yang sebenarnya ingin kita sampaikan. She found it was difficult because Indonesian and English has different sound system. ( If there were mispronounciation, they could change the meaning that we would like to deliver). In line with students' problems on pronounciation, Ramelan (1999:7) points out the nature of pronounciation problems in learning foreign language as follows: "Firstly, the problem is concerned with the identification of the foreign sounds. Learners have to remember their accoustics qualities so that they will be able to directly identify them in utterance. Secondly, the problem is concerned with the pronounciation of 
sounds by their speech organs. They should be able to hear and identify the accoustics quality of the foreign language sounds in order to be able to produce them. The last problem is concerned with the production of suprasegmental features like stress, lenght, pitch, and intonation".

As it is mentionend above that students' problems are different and the way they handle it different and the way E (Emma) dealt with this problem was to write down those words and do some rehearsal on them; repeating the words over and over. It can be observed that the subject did not work them out as a comprehensive way to deal with her problem. To be in a comprehensive way, a number of things should be put into consideration to explain this situation. A study conducted by Moedjito (2008) revealed that pronounciation is not suffieciently taught at schools. Things are worse that the teachers even confused what English varieties should be taught and are lack of the knowledge of what and the knowledge of how to teach pronounciation.

Gina experienced different problem from Emma. Her problem was on her focus. She (Gina) admitted that it took longer time for her to digest the text because of her lack of focus. She futhermore mentioned that when she was reading a long text her eyes blurred and she got distracted by her classmates' noisy voices. Gina: Masalah kendala yang sering saya alami adalah membaca bacaan seringkali tidak fokus dalam membaca sehingga dalam memahami saya sedikit lama untuk memahami. Saya tidak fokus membaca ketika membaca sebuah bacaan yang panjang seringkali mata saya menjadi kabur dan seringkali suara-suara berisik dari temanteman yang membuat konsentrasi saya terganggu. (The most frequent problem that I experienced was I did not focus on reading. As a result, I needed more time to understand the text. I did not focus reading a longer text because my blurred eyes and my classmates' noisy sounds.

Gaby highlighted some common problems related to technical things like the unconducive setting to do videotaping and the internet connection. Gaby: Kendala yang saya alami adalah ketika akan merekam ada suara bising dari luar yang berasal dari kendaraan dan kemudian ada suara anak kecil di rumah yang menganggu. Dan masalah lainnya ketika akan mengupload video sesuai dengan jam yang sudah ditetapkan namun jaringan internet kita lemah. (The problem that I experienced was that when I would record, there were noisy voices outside coming from vehichles and noisy voices of kids at home. Other problem is when I am going to upload my video as the secheduled hour, the connection was bad). Gaby mentioned that these problems were not big ones as she could handled them. The things that she did was to wait until there was no noisy voices and to calm down the kids so that she could do videotaping.

\section{The Benefits of Doing Videotaping}

The implementation of videotaping is perceived positively as revealed by all the students' response. It is interesting that Gaby is really aware of the benefit of being creative in order to face this revolution era, 4.0.

Gaby: Bagi saya manfaat dalam kegiatan ini adalah untuk melatih kreativitas karena dijaman sekarang anak muda dituntut akan kreativitas. Bagi saya kreatif adalah kemampuan untuk membuat suatu yang berbeda yaitu hal yang baru, menarik dan unik. Jika saya hanya merekam begitu saja itu adalah hal yang bisa dilakukan 
semua orang, karena bukan sesuatu yang sukar untuk menekan bulatan merah pada kamera sehingga video terekam. Namun ini berbeda, yang perlu dilakukan adalah ketika kami membuat video adalah melihat apakah latarnya bagus, angle nya tepat, dan kemudian video direkam dan kamipun harus mengedit warna font yang tepat, font style, tulisan, dsb. Hal ini tentunya membantu otak kita berpikir kreatif dan membuat video adalah salah satu cara untuk mengembangkan kreativitas. Menjadi kreatif dapat membuat kita berkembang dna bertahan didunia yang penuh dengan persaingan. (For me, the benefit of doing this activity is to train my creativity because creativity is much needed for young people in this era. I define creativity is an ability to make a different thing; novel, interesting and unique. If I only record as it is supposed to be, all people can make it because it is a piece of cake to press red button on the camera so that the video will be recorded. It is different. The thing that I needed to do was to consider about the background, angle, font, writing, and many more. This helps our brain to think creatively and doing videotaping is a way to develop our creativity. To be creative can make us developed and survive on this world full of competition. In line with what the subject vented out, Maley and Peachey (2015) explain that creativity is much needed to help humans to overcome the challenges by seeking ways-out and to discover and develop things to improve the quality of humans' life. No wonder, related to this fourth industrial revolution, one of the qualities should be possessed by the students is to be creative.

Other positive benefit exposed by Emma saying that videotaping helps her not only to hone her creativity but also helps her to improve her reading and critical thinking. Emma: Kegiatan ini membantu meningkatkan kemampuan membaca saya. Dalam proses membacaan materi secara tidak langsung juga melatih membaca kritis karena saya harus memahami poin-point penting yang nanti saya akan kembangkan menjadi sebuah presentasi. Semakin sering diulang maka ketrampilan membaca kitapun dapat terlatih dan bahkan meningkatkan kesukaan terhadap membaca. (This activity helps me to improve my reading ability. In reading process, indirectly, it trains my critical reading because I need to understand main and important points that will be developed into a presentation. The more I do this, the better my ability and it makes me to like reading).

Being able to read the texts criticically is important and is being promoted in all Indonesia's curriculum taught at schools and university and it is one of the skills that students should have in this 21st century despite the fact that . Wallace (2003) defines critical thinking as" the ability to critique the logic of the texts, to note inconsistencies and lack of clarity" (p. 27). There are eight criteria that students need to meet when they apply critical thinking in reading, i.e. the abilities to understand and determine the article's purpose, the key question, the most important information and ideas in the article, the key conclusions, the author's line of reasoning, the main assumptions underlying the author's thinking, the consequences upon accepting or rejecting the author's line of reasoning, and the author's main points of view (p.13).

\section{Conclusion}

This paper has presented how freshman students in pre-service training service perceive the implementation of videotaping on Reading course. The results of the study conclude that the students perceived its implementation positively as almost most of the subjects liked doing this since videotaping serves as a platform to hone 
Journal of Educational Method and Technology Vol. 2 No. 1, April 2019

P-ISSN 2622-8459 E-ISSN 2622-8467

http://ejournal.unima.ac.id/index.php/jemtec

their creativity, improve reading skills, reflect their learning, and express themselves despite the fact that they experienced tehnical, content and delivery problems.

\section{References}

Kohonen, V. 2005. Learning to learn through reflection-an experiental learning perspective in Teacher Development through reflective teaching in J.C. Richards and D. Nunan (eds). Second Language Teacher Education, (p.2022014). Cambridge University Press

Wallace. 2003

Ramelan. 1997. English Phonetics. Semarang : IKIP Semarang Press

Hussin, A.A. 2018. Education 4.0 Made Simpe: Ideas For teaching. International Jurnal of Educationa and Literacy Studies

Malley and Peachey. 2016. Creativity in the English Language Classroom. ELT Journal Volume 70 Issue 3 July

Moedjito. 2009. Priorities in English Pronunciation Teaching in EFL Classrooms.

Prensky, M. 2001. Digital Natives, Digital Immigrants. On the Horizon. MCB University Press Volume 9. No. 5

Prensky, M. 2006. Listen to the Natives. Educational Leadership. Volume 63 Number 4

Yudianthara, R.A \& Nasir, I. A. 2017. Toward Mobile-Assisted Language Learning (MALL): Reaping Mobile Phone Benefits in Classroom Activities. Register Journal, Language \& Language Teaching Journal Volume 10, No, 1 pp.12-18

Andy \& Suharto. 2017. Reading, Retellling, Rehearsal and Videotaping (RRRV) Untuk meningkatkan Kemampuan Berbicara Bahasa Inggris. Journal Ilmiah Bahasa dan Sastra Volume 4 Nomor 1

Nuttal, C. 1996. Teaching Reading Skills in Foreign Language. Oxford: Heinemann English Language Teaching 